$\xi=$ 圆

\title{
Evaluation of a multicomponent vaccine in dogs
}

\author{
A. Chowdhury ${ }^{1}$, D.G. Dighe ${ }^{2}$, R.D. Velhankar ${ }^{2}$, A. Sarkar ${ }^{3} *$, S. Nandi ${ }^{4}$ \\ ${ }^{1}$ Assistant Professor, Department of Veterinary Medicine, CVSc \& AH, R.K.Nagar, M.V.Sc. (Veterinary Medicine). \\ This article is the part of author's M.V.Sc thesis \\ ${ }^{2}$ Associate Professor, Department of Veterinary Medicine, Bombay Veterinary College \\ ${ }^{3}$ Assistant Professor, CVSc \& AH, R.K.Nagar, M.V.Sc. (Veterinary Virology), I.V.R.I., Izzatnagar, Bareily, U.P \\ ${ }^{4}$ Assistant Professor, Department of Veterinary Physiology and Biochemistry, CVSc \& AH, \\ R.K.Nagar, M.V.Sc. (Veterinary Biochemistry) \\ *Corresponding author E-mail: arunavasarkar222@gmail.com
}

\begin{abstract}
The concept of combined viral and bacterial vaccines has been tried in cattle, canine and humans. Use of multicomponent vaccines has numerous advantages over individual vaccine. In this study, apparently healthy 8-9 weeks old 41 puppies were divided into 2 groups. 31 puppies (test group) were vaccinated subcutaneously with a commercially available multicomponent vaccine containing live attenuated strains of Canine Distemper virus, Canine Adenovirus type 2, Canine Parvo virus and Canine Parainfluenza virus and inactivated antigens of Leptospira canicola and Leptospira icterohemorrhagiae. 10 puppies were kept unvaccinated (control). Test group puppies were given a booster after 4 weeks of primary vaccination. Serum samples from both the groups were collected on 4 occasions (0th, 28th, 42nd and 90th day) and were tested for antibody titres against Canine Distemper virus and Canine Adenovirus type 2 by Serum Neutralization test, against Canine Parvovirus and Canine Parainfluenzavirus by Haemagglutination Inhibition test and against Leptospira canicola and L. icterohemorrhagiae by Microscopic Agglutination Test. A significant rise (P 0.5) in antibody titres was observed against all the antigens after vaccination. The control group did not show significant variation in the antibody titres. All puppies vaccinated subcutaneously with this vaccine did not evoke any local/ adverse reactions.
\end{abstract}

Keywords: Vaccine; Virus; Multi-Component; Serum Neutralization Test; Microscopic Agglutination Test; Haemagglutination Inhibition Test; Antibody; Titre; ANOVA.

\section{Introduction}

There are several viral diseases that may occur in young puppies. Canine distemper and Infectious Canine Hepatitis viruses infect new born puppies and cause mortality. However, Canine Parvo viral diarrhea is more severe in puppies and may cause high mortality (up to 100\%) in them. Leptospirosis may occur in any age group of dogs, and it has got zoonotic importance. Leptospira serovars icterohemorrhagiae and canicola (Goldstein, 2005) are responsible for most clinical cases. Proper and timely vaccination of the pets is very important as it not only safe guards their lives but also indirectly protects us against exposure to deadly zoonotic disease like leptospirosis.

The development of multicomponent vaccine have initiated a new era in the field of Medicine to confer immunity to the animals against multiple diseases. The concept of combined viral and bacterial vaccines has been tried in species like cattle, canine and humans. Use of combined or multicomponent vaccines has numerous advantages over individual vaccine, as it reduces the number of vaccination, dropouts, stress and easy for follow up and record keeping. Administration of two doses of multicomponent vaccine to pups and kittens between 8 and 16 weeks age has become a standard and important part of cost effective veterinary healthcare for the susceptible neonatal populations (Day, 2007). In pet animals, multicomponent vaccines that include antigenic components like Canine Distemper virus, Canine Parvo virus, Canine Parainfluenza virus, Canine Adenovirus type- 1 or type- 2 and Lep- tospira canicola and L. icterohemorrhagiae have been used. Studies carried out so far demonstrated that these multicomponent vaccines could induce a protective immune response in dogs without any apparent side effects.

The AVMA (American Veterinary Medical Association) council on Biologic and Therapeutic Agents' report on dog and cat vaccination has recommended core vaccine for dogs to include $\mathrm{Ca}$ nine Distemper virus, Canine Adenovirus-2 (hepatitis and respiratory disease), Canine Parvo virus and Rabies while non-core vaccine include Leptospirosis, Corona virus, Canine Parainfluenza and Bordetella bronchiseptica (both cause kennel cough) and Borrelia burgdorferi (canine Lyme disease).

Efficacy of the vaccine is determined by its ability to stimulate immune system and resulting in increased antibody production that protects animals against deadly diseases. While developing the vaccine a number of factors are to be taken into consideration, so that the vaccine that is evolved will have only protective effect from all the components incorporated in it rather than causing immune suppressive effects in animals due to their individual influences (Phillips et al., 1989). All the components of multicomponent vaccine are not equally effective, and some sorts of disparity have been reported in their ability of eliciting immune response in the animals. Many new multicomponent vaccines are being developed to overcome these problems and being evaluated carefully for their efficacy and safety, so that after immunization all the components will induce a good immune response in the animals against those diseases with no or minimal adverse reaction. 
The present study was undertaken to observe the antibody titers of all the components of multicomponent vaccine at different intervals and to record any adverse reactions during and after immunization.

\section{Materials and methods}

The present study was carried out on forty one apparently healthy, unvaccinated pups (aged between 8-9 weeks) brought to the OPD (Out Patient Department), Bombay Veterinary College or referred by private practitioners for vaccination. All the pups selected in this study were of either sex and of different breeds. The pups were divided into two groups, i.e. Group-I/ Test group and GroupII/ Control group. In the test group, 31 puppies were selected and complete clinical examination was conducted to ensure their optimum health. All the puppies were dewormed using the oral deworming medicine Drontal Plus given as a dose rate of 1 tablet per $10 \mathrm{~kg}$ body weight. All the test group puppies were injected with the multicomponent vaccine (Megavac7) subcutaneously (S/C) An additional booster dose was given by the same route on the $28^{\text {th }}$ day to elicit an anamnestic response. In the control group, 10 puppies were selected and no vaccine shot was given to them. About $3 \mathrm{ml}$ of blood was collected from either the cephalic or saphenous vein, in the sterile vacuum container (test tubes) containing clot activator and then serum was separated and stored at $23^{\circ} \mathrm{C}$ without any preservatives until further tests. All the puppies were monitored after primary vaccination for any local and systemic adverse effects up to 90 days. The Serum Neutralization test (SNT) for CDV (Canine Distemper virus) and CAV2 (Canine Adenovirus type 2) and Haemagglutination Inhibition test (HI) for CPV (Canine Parvovirus) \& CPiV (Canine Parainfluenza virus) and Microscopic Agglutination test (MAT) for Leptospira canicola \& Leptospira icterohemorrhagiae were performed at the Quality Control Division of the Indian Immunologicals Ltd., Hyderabad to estimate the serum antibody titres on $0^{\text {th }}, 28^{\text {th }}, 42^{\text {nd }}$ and $90^{\text {th }}$ days against those above-mentioned components. The antibody titers considered as protective titers against the enlisted diseases were as per Indian Immunological Ltd., Quality Control Division, Hyderabad (A.P.).

\subsection{Procedure of serum neutralization test (SNT)}

All the serum samples were incubated in a water bath at $56^{\circ} \mathrm{C}$ for 30 minutes prior to testing. $50 \mu \mathrm{l}$ of test serum was taken in the wells of a 96 well flat bottom Microtest tissue culture plate and then $50 \mu 1$ of TC mono media (Tissue culture mono media) was added to all the wells. A two-fold serial dilution $(0.3 \mathrm{log})$ of the serum samples were made based on the expected titre. $50 \mu$ of 100 TCID50 ( 2 log virus) virus suspension in TC mono media was added to all the wells of the tissue culture plate. Thus serum-virus mixture was kept for incubation at $37^{\circ} \mathrm{C}$ for $90-120$ minutes $\left(1 \frac{1}{2}\right.$ to 2 hours) in a $5 \% \mathrm{CO} 2$ incubator. Madin-Darby Canine Kidney (MDCK) cell culture for SNT of CAV2 and Vero cells for CDV were used. After incubation of plates $50 \mu 1$ of MDCK cell culture and $50 \mu \mathrm{l}$ of Vero cells were added to all the wells of CAV2 plates and CDV plates respectively. Then plates were kept for incubation for 5 days at $37^{\circ} \mathrm{C}$ in a $5 \% \mathrm{CO} 2$ incubator. After incubation plates were observed under inverted microscope and all the wells of the microtitre plate were checked for any cytopathic effect development. Serum Neutralization antibody titres are the reciprocal of maximum dilution of serum inhibiting the 100TCID50 CDV specific cytopathic effects. The antibody titre estimation was done by using the Spearman Karben formula given below:

Serum Neutralization antibody titre $=\log$ of highest dilution $+\log$ step/2 - (no. of wells with CPE x log step/ no. of wells per dilution)

\subsection{Procedure of haemagglutination inhibition test (HI)}

All the serum samples were incubated in a water bath at $56^{\circ} \mathrm{C}$ for 30 minutes prior to testing. Non-specific inhibitors of viral haemagglutination were removed by the treatment of sera before testing by kaolin. In a micro centrifuge tube, $900 \mu$ of Kaolin $(20 \%$ $\mathrm{w} / \mathrm{v})$ solution was taken, and to that $100 \mu \mathrm{l}$ of test serum was added. The Kaolin-serum mixture was kept in the Vortex for proper mixing for $10-20$ minutes and then centrifuged at $2000 \mathrm{rpm}$ for 10 minutes. After that supernatant was collected and to that $100 \mu \mathrm{l}$ of $50 \%$ of pig / monkey RBC (for CPV) or $50 \%$ of chicken RBC (for $\mathrm{CPiV}$ ) was added and then it was incubated at $+4^{\circ} \mathrm{C}\left(2-8^{\circ} \mathrm{C}\right)$ for 1 hour. After incubation, mixture was centrifuged at $2000 \mathrm{rpm}$ for 10 minutes and again supernatant was separated, and then it was kept as test sample for the HI test. $25 \mu \mathrm{l}$ of test sample was dispensed to the first wells of the column of 96 wells ' $U$ ' bottom microtitre plate. Thereafter, $25 \mu$ of saline (cold) was added to all the wells and two-fold serial dilution of the sample was done. $1 \mathrm{ml}$ of $8 \mathrm{HA}$ for (CPV) and $4 \mathrm{HA}$ (for $\mathrm{CPiV}$ ) virus in cold saline (diluents) was used for this test. After dilution of the sample, $50 \mu \mathrm{l}$ of virus was added to all wells. $50 \mu \mathrm{l}$ of $1 \%$ pig or monkey RBC (for $\mathrm{CPV}$ ) or $1 \%$ chicken $\mathrm{RBC}$ (for $\mathrm{CPiV}$ ) was added to all the wells of the plate. Then it was incubated at $2-8^{\circ} \mathrm{C}$ for 2 hours (for CPV) or Room temperature $\left(25^{\circ} \mathrm{C}\right.$ ) for 1 hour (for $\left.\mathrm{CPiV}\right)$. After incubation, the plates were placed in the reading mirror to observe the readings. The wells showing diffuse sheet of agglutinated RBCs covering the bottom were considered as HI negative and wells showing well circumscribed button of unagglutinated RBCs were considered as HI positive. The HI end-point titre was considered as the dilution factor of the highest serum dilution where a clear button was seen.

\subsection{Procedure of microscopic agglutination test (MAT)}

All the serum samples were incubated in a water bath at $56^{\circ} \mathrm{C}$ for 30 minutes prior to testing. The test serum samples were diluted to 1:25 dilution with PBS (Phosphate Buffer Solution). $50 \mu$ of the sterile PBS was added to all the wells of 96 well ' $U$ ' bottom microtitre plate. Then $50 \mu \mathrm{l}$ of 1: 25 diluted sera samples were dispensed to first wells of column and sera samples were diluted serially from row A to $\mathrm{H}$. After dilution of the test sera samples 50 $\mu 1$ of Leptospira culture ( $1-2 \times 108$ organisms / ml) was added to all the wells and incubated at room temperature $\left(25^{\circ} \mathrm{C}\right)$ for two hours. After incubation, each dilution chamber was examined under dark field microscope for the presence of micro agglutinations (MAT).The The dilution which shows the 50\% agglutination of leptospires was considered as microscopic agglutination titre (MAT) i.e. positive titre.

\subsection{Statistical analysis}

The results of SNT and HI for the two groups were analyzed as per the standard methods outlined by Snedecor and Cochran (1994) by using Completely Randomized Design (CRD) and Fisher's test/ Variance ratio test.

Megavac7 vaccine was supplied by Indian Immunologicals Ltd., Hyderabad (A.P.)

\section{Results}

In this research work, a component wise serological response of multicomponent vaccine in puppies was studied and compared with available literatures.

\subsection{Canine distemper virus (CDV)}

The Mean \pm S.E. CDV serum antibody titre values of test group samples on $0^{\text {th }}, 28^{\text {th }}, 42^{\text {nd }}$ and $90^{\text {th }}$ days were $12.65 \pm 1.73,41.29 \pm$ $5.41,129.03 \pm 64.67$ and $323.09 \pm 121.54 \mathrm{IU} / \mathrm{ml}$ respectively. The 
serum values on $0^{\text {th }}, 28$ th; 42 nd and $90^{\text {th }}$ days differed significantly $(\mathrm{P} \leq 0.5)$ (Fig.1).

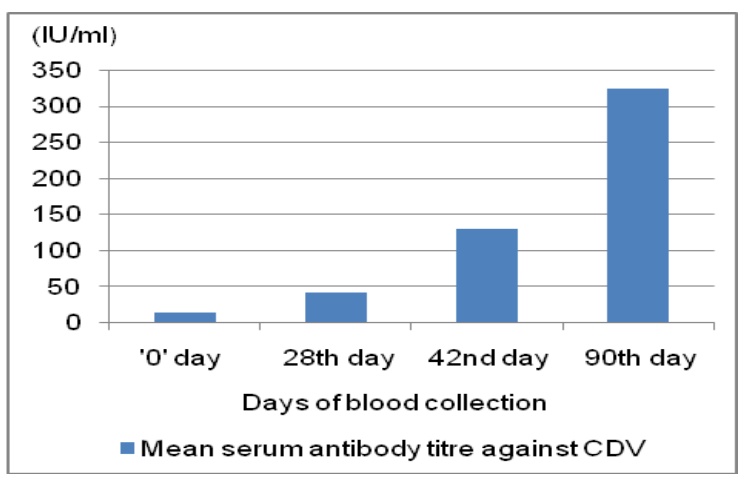

Fig. 1: Rise of Mean Serum Neutralization Antibody Titres (IU/Ml) Against CDV on Different Days after Immunization. (Test Group).

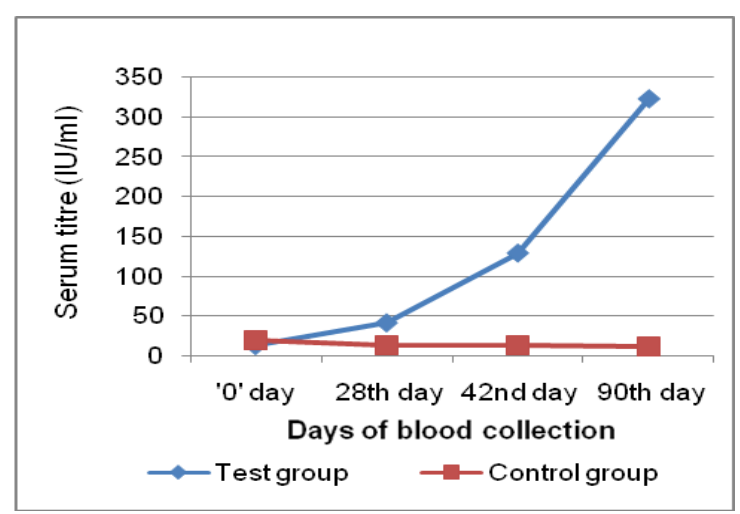

Fig. 2: Comparison of Mean CDV Serum Antibody Titres (IU/Ml) On Different Days between Test Group and Control Group Puppies.

There was a gradual rise in antibody titre with a peak on $90^{\text {th }}$ day after vaccination. The Mean \pm S.E serum antibody titre values of control group samples on $0^{\text {th }}, 28^{\text {th }}, 42^{\text {nd }}$ and $90^{\text {th }}$ days were $19.2 \pm$ $3.77,12.8 \pm 2.66,12.8 \pm 2.66$ and $12 \pm 3.38 \mathrm{IU} / \mathrm{ml}$ respectively. The serum antibody titres of both the groups against CDV differed significantly ( $\mathrm{P} \leq 0.5)$ (Table 1, Fig.2).

\subsection{Canine adenovirus type-2 (CAV2)}

In the present study, the estimated Mean \pm S.E. serum neutralizing antibody titres of test group puppies against CAV2 were $129.94 \pm$ $1.88,3703.74 \pm 172.77,4029.94 \pm 66.07$ and $3402.32 \pm 203.65$ $\mathrm{IU} / \mathrm{ml}$ on $0^{\text {th }}$ day, $28^{\text {th }}$ day, $42^{\text {nd }}$ day and $90^{\text {th }}$ day respectively. CAV2 antibody titres increased significantly $(\mathrm{P} \leq 0.5)$ as compared with the control group (Table 2, Fig.4).

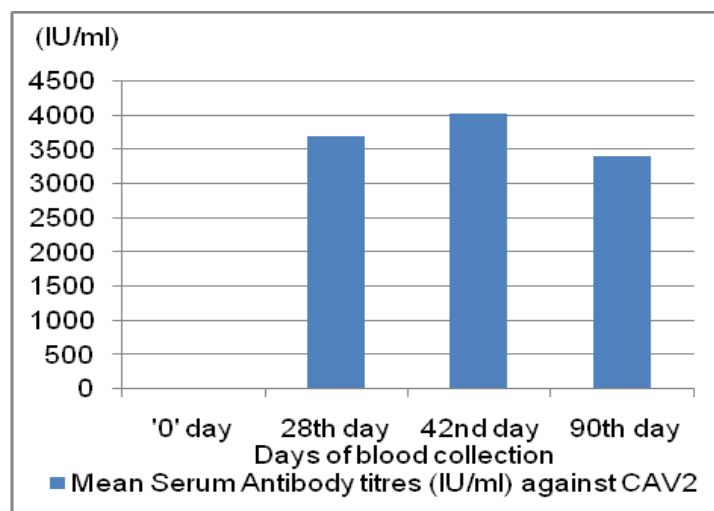

Fig. 3: Rise of Mean Serum Neutralization Antibody Titres (IU/Ml) Against CAV2 on Different Days after Immunization. (Test Group).
Table 1: Mean \pm S.E. CDV Antibody Titres (IU/Ml) of Test Group Puppies and Their Critical Difference (C.D.)

\begin{tabular}{llllll} 
Parameter & Days & $\begin{array}{l}\text { Mean } \pm \text { S.E. } \\
\text { Antibody titres } \\
(\mathrm{IU} / \mathrm{ml})\end{array}$ & $\mathrm{F}_{\text {cal }}$ & $\mathrm{F}_{\text {tab }}$ & C.D. \\
\hline CDV compo- & $0^{\text {th }}$ & $12.65 \pm 1.73^{\mathrm{a}}$ & & & \\
nent & $48^{\text {th }}$ & $\begin{array}{l}41.29 \pm 5.41^{\mathrm{a}} \\
129.03 \pm 64.67^{\mathrm{a}}\end{array}$ & 4.13 & 2.68 & 192.89 \\
& $42^{\text {th }}$ & $323.09 \pm 121.54^{\mathrm{b}}$ & & & \\
\hline
\end{tabular}

Mean should be read row wise. Mean showing dissimilar superscripts differ significantly. $\mathrm{t} 0.05$ value at 120 degrees of freedom is 1.98 .

Table 2: Mean \pm S.E. CAV2 Antibody Titres (IU/Ml) of Test Group Puppies and Their Critical Difference (C.D.)

\begin{tabular}{|c|c|c|c|c|c|}
\hline Parameter & Days & $\begin{array}{l}\text { Mean } \pm \text { S.E. Antibody } \\
\text { titres }(\mathrm{IU} / \mathrm{ml})\end{array}$ & $F_{\text {cal }}$ & $\mathrm{F}_{\text {tab }}$ & C.D. \\
\hline $\begin{array}{l}\text { CAV2 } \\
\text { component }\end{array}$ & $\begin{array}{l}0^{\text {th }} \\
28^{\text {th }} \\
42^{\text {nd }} \\
90^{\text {th }}\end{array}$ & $\begin{array}{l}9.94 \pm 1.88^{\mathrm{a}} \\
3703.74 \pm 172.77^{\mathrm{b}} \\
4029.94 \pm 66.07^{\mathrm{b}} \\
3402.32 \pm 203.65^{\text {bd }}\end{array}$ & 184.58 & 2.68 & 385.13 \\
\hline
\end{tabular}

Mean should be read row wise. Mean showing dissimilar superscripts differ significantly. $\mathrm{t} 0.05$ value at 120 degrees of freedom is 1.98 .

Table 3: Mean \pm S.E. CPV Antibody Titres (IU/Ml) of Test Group Puppies and Their Critical Difference (C.D.)

\begin{tabular}{|c|c|c|c|c|c|}
\hline Parameter & Days & $\begin{array}{l}\text { Mean } \pm \text { S.E. Antibody } \\
\text { titres }(\mathrm{IU} / \mathrm{ml})\end{array}$ & $\mathrm{F}_{\text {cal }}$ & $\mathrm{F}_{\text {tab }}$ & C.D. \\
\hline $\begin{array}{l}\text { CPV com- } \\
\text { ponent }\end{array}$ & $\begin{array}{l}0^{\text {th }} \\
28^{\text {th }} \\
42^{\text {nd }} \\
90^{\text {th }}\end{array}$ & $\begin{array}{l}32.26 \pm 2.88^{a} \\
6616.77 \pm 683.59^{b} \\
3396.13 \pm 518.12^{c} \\
4872.26 \pm 676.68^{d}\end{array}$ & 26.17 & 2.68 & 772.43 \\
\hline
\end{tabular}

Mean should be read row wise. Mean showing dissimilar superscripts differ significantly. $\mathrm{t} 0.05$ value at 120 degrees of freedom is 1.98 .

Table 4: Mean \pm S.E. Cpiv Antibody Titres (IU/Ml) of Test Group Puppies and Their Critical Difference (C.D.)

\begin{tabular}{|c|c|c|c|c|c|}
\hline Parameter & Days & $\begin{array}{l}\text { Mean } \pm \text { S.E. Antibody } \\
\text { titres }(\mathrm{IU} / \mathrm{ml})\end{array}$ & $\mathrm{F}_{\text {cal }}$ & $\mathrm{F}_{\mathrm{tab}}$ & C.D. \\
\hline $\begin{array}{l}\mathrm{CPiV} \\
\text { component }\end{array}$ & $\begin{array}{l}0^{\text {th }} \\
28^{\text {th }} \\
42^{\text {nd }} \\
90^{\text {th }}\end{array}$ & $\begin{array}{l}20 \pm 0^{\mathrm{a}} \\
63.87 \pm 7.62^{\mathrm{b}} \\
108.39 \pm 8.34^{\mathrm{c}} \\
141.94 \pm 6.11^{\mathrm{d}}\end{array}$ & 68.39 & 2.68 & 17.97 \\
\hline
\end{tabular}

Mean should be read row wise. Mean showing dissimilar superscripts differ significantly. $\mathrm{t} 0.05$ value at 120 degrees of freedom is 1.98 .

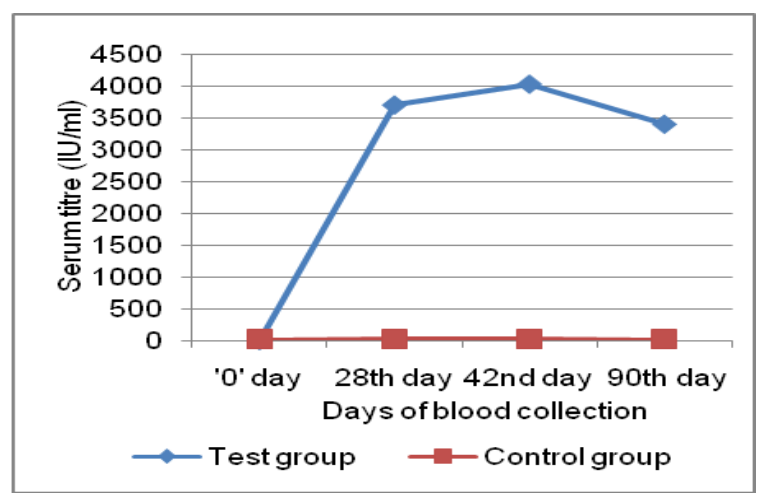

Fig. 4: Comparison of Mean CAV2 Serum Antibody Titres (IU/M1) on Different Days between Test Group and Control Group Puppies.

Abdelmagid et al. (2004) in their study on efficacy of multicomponent vaccine in beagle pups also recorded a significant rise in CAV2 serum antibody titres (CAV2 neutralizing antibody titres were $<2,>3,385,1,473,>2,312,558,>3$ and 628 on $0^{\text {th }}$ day, $21^{\text {st }}$ day, $36^{\text {th }}$ day, $42^{\text {nd }}$ day, $57^{\text {th }}$ day and $90^{\text {th }}$ day respectively). 


\subsection{Canine parvovirus (CPV)}

In the present study, only serological response of multicomponent vaccine in the test group was evaluated comparing with the control group. Results indicated a significant rise $(\mathrm{P} \leq 0.5)$ in the mean CPV HI antibody titres in the test group samples (Table 3 and Fig.5) as compared with control group which did not show any rise in the antibody titres (Mean \pm S.E. $20 \pm 0 \mathrm{IU} / \mathrm{ml}$ ) from $0^{\text {th }}$ day to $90^{\text {th }}$ day (Fig.6). These observations are in the agreement with the study of Spibey et al. (2007).

\subsection{Canine parainfluenza virus (CPiV)}

Post vaccinal $\mathrm{HI}$ antibody titres in the present study were estimated in both test and control groups. The HI antibody titres in the test group rose significantly $(\mathrm{P} \leq 0.5)$ than the values prior to vaccination (Fig.7) and in control group (Fig.8). The Mean \pm S.E. HI antibody titre values of test group samples were $20 \pm 0,63.87 \pm$ $7.62,108.39 \pm 8.34$ and $141.94 \pm 6.11 \mathrm{IU} / \mathrm{ml}$ on $0^{\text {th }}, 28^{\text {th }}, 42^{\text {nd }}$ and $90^{\text {th }}$ day respectively, but Mean \pm S.E. HI antibody titre values of control group were remained same $(20 \pm 0 \mathrm{IU} / \mathrm{ml})$ on these four occasions i.e. $0^{\text {th }}, 28^{\text {th }}, 42^{\text {nd }}$ and $90^{\text {th }}$ days shown in table 4 . This present study observations are in the same line with the findings of Jacobs et al. (2005).

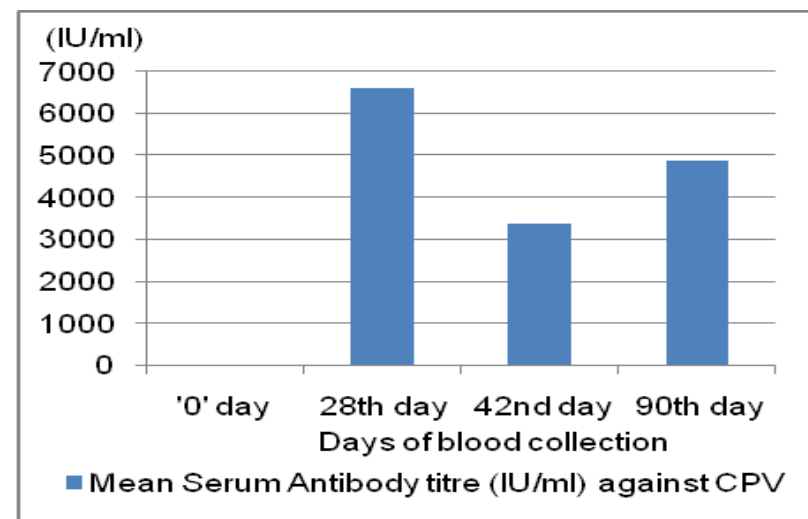

Fig. 5: Rise of Mean Haemagglutination Inhibition Antibody Titres (IU/Ml) Against CPV on Different Days after Immunization. (Test Group).

Since Microscopic Agglutination test (MAT) is a qualitative test so statistics can't be applied in this case. The 1:100 antibody titre is a protective titre and can be read as positive and below that titre value read as negative i.e. no or negligible amount of microscopic clump or agglutinin formation.

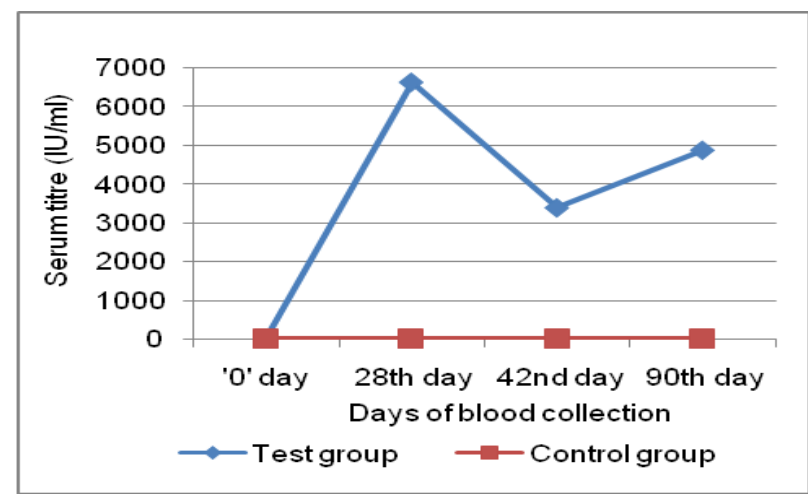

Fig. 6: Comparison of Mean CPV HI Antibody Titres (IU/Ml) on Different Days between Test Group and Control Group Puppies.

\subsection{Leptospira canicola}

All the 0th day sera samples were negative. Out of 31 test samples, 22 samples showed positive titre on 28th day and on 42nd and 90th day all the samples were found positive. All the control samples were found negative as they were not given any vaccina- tion. In the vaccinated group for Leptospira canicola, there was increase in titres from negative on $0^{\text {th }}$ day to $1: 100$ (protective titre) / 1:200 on $90^{\text {th }}$ day. Only in $6.45 \%$ cases $(2$ in 31$)$, the titre did not increase even after booster vaccination. Observations in the present study are in agreement with the findings of Birnbaum (1998).

\subsection{Leptospira icterohemorrhagiae}

All the $0^{\text {th }}$ day sera samples were negative. Out of 31 samples 29 samples showed positive titre on $28^{\text {th }}, 42^{\text {nd }}$ and $90^{\text {th }}$ days after vaccination. All the control samples were found negative as they were not given any vaccination.

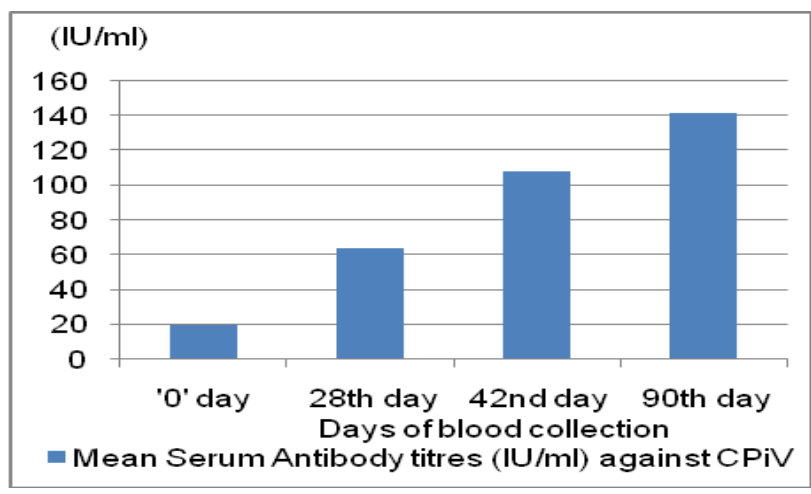

Fig. 7: Rise of Mean Haemagglutination Inhibition Antibody Titres (IU/Ml) Against CPIV on Different Days after Immunization. (Test Group).

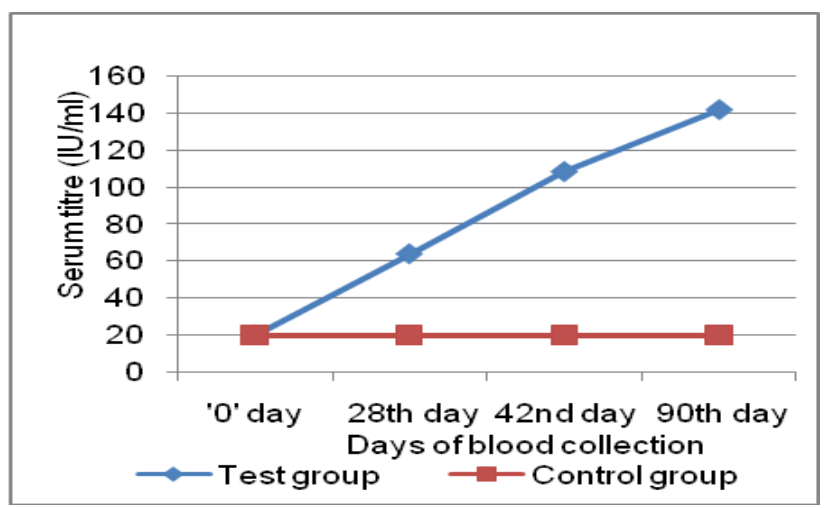

Fig. 8: Comparison of Mean CPIV HI Antibody Titres (IU/M1) on Different Days between Test Group and Control Group Puppies.

In the present study, the pre and post vaccinal titres were estimated in both the group's viz. test and control for both Leptospira canicola and Leptospira icterohemorrhagiae. Observations indicated a rise in MAT antibody titres from negative to 1:100 / 1:200 in test group whereas, as expected, no change was observed in the values of control group. This study is in the agreement of the study conducted by Klaasen et al. (2003) except that the challenge experimental study was beyond the purview of the present study.

\section{Discussion}

Present study reported significantly increased $(\mathrm{P} \leq 0.5)$ serum neutralizing antibody titres on $90^{\text {th }}$ day against CDV in test group puppies as compared with the control group. These observations are in the agreement with the observation recorded by Gore et al. (2005). The observations of the present study are in the same line with the author's value. The variation observed in the values reported by the author could be due to the breed of dogs, type of vaccine used and individual immune response. Test group puppies in this study showed significantly rise $(\mathrm{P} \leq 0.5)$ in CAV2 serum neutralizing antibody titres after vaccination (Fig.3) whereas, the control group puppies did not show any significant variation in the 
antibody titres (Fig.4). Mouzin et al. (2004) reported CAV1 and CAV2 titres in 320 dogs and found that titres rose to $100 \%$ after revaccination from initial Serum neutralizing antibody titres at $\geq$ 1:16 level. The present study results are in agreement with those reported by the author. In the present study, only serological response of multicomponent vaccine in the test group was evaluated comparing with the control group. Results indicated a significant rise $(\mathrm{P} \leq 0.5)$ in the mean $\mathrm{CPV} \mathrm{HI}$ antibody titres in the test group samples (Table 3 and Fig.5) as compared with the control group which did not show any rise in the antibody titres (Mean \pm S.E. 20 $\pm 0 \mathrm{IU} / \mathrm{ml}$ ) from $0^{\text {th }}$ day to $90^{\text {th }}$ day (Fig.6). These observations are in the agreement with the study of Spibey et al. (2007). Post vaccinal HI antibody titres in the present study were estimated in both test and control groups. The HI antibody titres in the test group rose significantly $(\mathrm{P} \leq 0.5)$ than the values prior to vaccination (Fig.7) and in control group (Fig.8). The Mean \pm S.E. HI antibody titre values of test group samples were $20 \pm 0,63.87 \pm 7.62$, $108.39 \pm 8.34$ and $141.94 \pm 6.11 \mathrm{IU} / \mathrm{ml}$ on $0^{\text {th }}, 28^{\text {th }}, 42^{\text {nd }}$ and $90^{\text {th }}$ day respectively, but Mean \pm S.E. HI antibody titre values of control group were remained same $(20 \pm 0 \mathrm{IU} / \mathrm{ml})$ on these four occasions, i.e. $0^{\text {th }}, 28^{\text {th }}, 42^{\text {nd }}$ and $90^{\text {th }}$ days. These present study observations are in the same line with the findings of Jacobs et al. (2005).

In the present study, the pre and post vaccinal titres were estimated in both the group's viz. test and control for both Leptospira canicola and Leptospira icterohemorrhagiae. Observations indicated a rise in MAT antibody titres from negative about 1:100 / 1:200 in test group whereas, as expected, no change was observed in the values of control group. This study is in the agreement of the study conducted by Klaasen et al. (2003) except that the challenge experimental study was beyond the purview of the present study. Most of the puppies of Test and Control groups showed initial $\left(0^{\text {th }}\right.$ day) low levels of titres against CDV, CAV2, CPV, CPiV and Leptospirosis. However, there was a significant rise to the antibody titres in the puppies after vaccination against all those diseases. This indicated that the multicomponent vaccine used in the present study could overcome the interference of maternal antibodies after immunization. This is in agreement with the observation reported by Pratelli et al., 2000.

No adverse effects were observed in the puppies after vaccination with the multicomponent vaccine used in the present study. However, adverse effects like encephalitis (Bestetti et al., 1978; Cornwell et al., 1988 and Krakowka et al., 1982), severe gastroenteritis (Decaro et al., 2006), vaccine-associated immune-mediated haemolytic anemia (Duval et al., 1996) etc. have been reported in the dogs following vaccination. These are in disagreement with the observation of present study. This multicomponent vaccine used in the puppies generated excellent serological response (Serum Neutralizing antibodies for CDV and CAV-2 viral antigenic components incorporated in it, making it suitable immunizing agent in dogs for protecting them against these deadly diseases. The vaccine was found to be safe in its use as none of the puppies suffered from any sort of local or generalized adverse reaction after primary or booster immunization. This vaccine was found to be safe for its use at the age between 8-9 weeks for primary immunization and three weeks thereafter for booster immunization and thus, age between 8-9 weeks can be recommended for its use in dogs for their routine immunization with this vaccine. Subcutaneous route of administration for this vaccine was found to be convenient, suitable, safe and effective eliciting excellent immune response. However, present study did not evaluate its efficacy by intramuscular or other routes of administration. The vaccine elicited good immunological response for the both Leptospira serovars viz. L. Canicola and L. Icterohemorrhagiae and thus, it can be useful to protect the dogs from Leptospirosis, which has zoonotic importance.

\section{References}

[1] Abdelmagid, O.Y., Larson, L., Payne, L., Tubbs, A., Wasmoen, T. and Schultz, R. (2004). Evaluation of the efficacy and duration of immunity of a canine combination vaccine against virulent parvovirus, infectious canine hepatitis virus, and distemper virus experimental challenges. Vet. Ther. 2004 Fall; 5(3):173-86.

[2] Bestetti, G., Fatzer, R. and Fankhauser, R. (1978). Encephalitis following vaccination against distemper and infectious hepatitis in the dog. J. Acta. Neuropathologica, Springer Berlin, 43(1-2): 69-75.

[3] Birnbaum, N., Barr, S.C. and Center, S.A. (1998). Naturally acquired leptospirosis in 36 dogs: serological and clinic-pathological features. J. Small. Anim. Pract.; 39:231-236. https://doi.org/10.1111/j.1748-5827.1998.tb03640.x.

[4] Cornwell, H.J., Thompson, H., McCandlish, I.A., Macartney, L. and Nash, A.S. (1988). Encephalitis in dogs associated with a batch of canine distemper (Rockborn) vaccine. Vet Rec. Jan 16; 122 (3):54-9.

[5] Day, M.J. (2007). Vaccine Safety in the Neonatal period. Journal of Comparative Pathology, Vol. 137, Suppl.1. pp. 51-56. https://doi.org/10.1016/j.jcpa.2007.04.019.

[6] Decaro, N., Desario, C., Elia, G., Campolo, M., Lorusso, A., Mari, V., Martella, V. and Buonavoglia, C. (2006). Occurrence of severe gastroenteritis in pups after canine parvovirus vaccine administration: A clinical and laboratory diagnostic dilemma. Vaccine 25 (2007):1161-1166

[7] Duval, D. and Giger, U. (1996). Vaccine-Associated ImmuneMediated Hemolytic Anemia in the Dog. Journal of Veterinary Internal Medicine, 10 (5): 290 -295. https://doi.org/10.1111/j.19391676.1996.tb02064.x.

[8] Goldstein, R.E. (2005). Canine Leptospirosis In: Proceedings15th ECVIM-CA Congress, Glasgow, 84-87.

[9] Gore, T.C., Lakshmanan, N., Duncan, K.L., Coyne, M.J., Lum, M.A. and Sterner, F.J. (2005). Three-Year Duration of Immunity in Dogs Following Vaccination against Canine Adenovirus Type-1, Canine Parvovirus and Canine Distemper Virus. Veterinary Therapeutics, Vol. 6, No. 1. pp. 5-14.

[10] Jacobs, A. A., Theelen, R.P., Jaspers, R., Horspool, L.J., Sutton, D., Bergman, J.G. and Paul, G. (2005). Protection of dogs for 13 months against Bordetella bronchiseptica and canine parainfluenza virus with a modified live vaccine. The Veterinary Record, 157:19 23. https://doi.org/10.1136/vr.157.1.19.

[11] Klaasen, H. L. B. M., Molkenboer, M.J.C.H., Vrijenhoek, M.P. and Kaashoek, M.J. (2003). Duration of immunity in dogs vaccinated against leptospirosis with a bivalent inactivated vaccine. Veterinary Microbiology, Vol. 95, Issues 1-2, 29:121-132.

[12] Krakowka, S., Olsen, R.G., Axthelm, M.K., Rice, J. and winters, K. (1982). Canine parvovirus infection potentiates canine distemper encephalitis attributable to modified live-virus vaccine. J. Am. Vet. Med. Assoc.; 180 (2):137-9.

[13] Mouzin, D. E., Lorenzen, M.J., Haworth, J.D. and King, V.L. (2004). Duration of serologic response to five viral antigens in dogs Journal of the American Veterinary Medical Association, 224:5560. https://doi.org/10.2460/javma.2004.224.55.

[14] Phillips, T.R., Jensen, J.L., Rubino, M.J., Yang, W.C. and Schultz, R.D. (1989). Effects of vaccines on the canine immune system. Can. J. Vet. Res.; 53:154-60.

[15] Pratelli, A., Cavalli, A., Normanno, G., De Palma, M.G., Pastorelli, G., Martella, V. and Buonavoglia, C. (2000). Immunization of Pups with Maternally Derived Antibodies to Canine Parvovirus (CPV) Using a Modified-Live Variant (CPV-2b). Journal of Veterinary Medicine, Series B, 47(4): 273-276. https://doi.org/10.1046/j.14390450.2000.00340.x.

[16] Snedecor, G.W. and Cochran, W.G. (1994). Statistical Methods. 8th Edn. Affiliated East West Press.

[17] Spibey, N., Greenwood, N.M., Sutton, D., Chalmers, W.S.K. and Tarpey, I. (2007). Canine parvovirus type-2 vaccine protects against virulent challenge with type $2 \mathrm{c}$ virus. Journal of Veterinary Microbiology; https://doi.org/10.1016/j.vetmic.2007.09.015.
128(1-2):48-55. 